\title{
Evidence for the presence of luteinizing hormone-chorionic gonadotrophin receptors in the pig umbilical cord
}

\author{
G. Wasowicz ${ }^{1}$, K. Derecka ${ }^{1}$, A. Stepien ${ }^{1}$, L. Pelliniemi ${ }^{2}$, T. Doboszynska ${ }^{1}$, \\ B. Gawronska ${ }^{1}$ and A. J. Ziecik ${ }^{1 *}$ \\ ${ }^{1}$ Division of Reproductive Endocrinology, Institute of Animal Reproduction and Food Research \\ of Polish Academy of Sciences, 10-718 Olsztyn, Poland; and ' University of Turku, Kiinamyllynkatu 10, \\ SF 20520 Turku, Finland
}

\begin{abstract}
Pig umbilical cord, like that of humans, contains two arteries and a vein surrounded by Wharton's jelly with amnion covering the exterior surface. The aim of the present study was to investigate whether $\mathrm{LH}-\mathrm{hCG}$ receptors are present in the pig umbilical cord, using light microscope immunohistochemistry, semiquantitative autoradiography, western blotting and reverse transcription-polymerase chain reaction. Umbilical cords were collected on days 48,71 and 103 of fetal life $(n=6)$. Monoclonal and polyclonal anti-LH receptor antibodies were used to study receptor distribution. Immunoreactivity was observed in the umbilical blood vessels, the epithelium of umbilical amnion and cells in the Wharton's jelly. No differences in LH-hCG receptor distribution related to the sex of the fetus, period of fetal life or section of the umbilical cord were observed. Strong immunostaining was observed in umbilical vein and in umbilical arteries. However, in the arteries, the tunica media expressed weaker receptor immunostaining than did the tunica intima and tunica adventitia. No immunoactivity was detected in non-target tissue (skeletal muscle) but $\mathrm{LH}$ receptors were immunostained in the pig ovary. Topical autoradiography showed that vein and arteries in the umbilical cord bind ${ }^{125}$ I-labelled hCG, which was highly diminished after co-incubation with an excess of unlabelled hCG. The binding of ${ }^{125}$ I-labelled hCG to the Wharton's jelly and epithelial amnion was less intense than it was to vessels. Gonadotrophin binding sites were not present in the skeletal muscle. The pig umbilical arteries, vein and Wharton's jelly contained a $75 \mathrm{kDa}$ immunoreactive LH-hCG receptor protein similar to that found in corpora lutea. Southern blot analysis of reverse transcription-polymerase chain reaction products, performed to enhance the sensitivity and specificity of $\mathrm{LH}$ receptor transcripts determination in umbilical cord tissues, revealed that the expected fragments of 740 and $470 \mathrm{bp}$ were present in the arteries, vein, Wharton's jelly and corpora lutea (positive control). An additional product of $670 \mathrm{bp}$ was found in the corpora lutea and arteries of umbilical cord, but not in the vein and Wharton's jelly. This is probably the first reported evidence of the presence of LH-hCG receptors in the umbilical cord of a non-human female mammal.
\end{abstract}

\section{Introduction}

The effect of LH and its agonist, hCG, on extragonadal tissues, such as myometrium, is mediated through binding to the same receptors. Uterine LH-hCG receptors are found in pigs (Ziecik et al., 1986) and their presence has been also confirmed in rabbits (Jensen and Odell, 1988; Sawitzke and Odell, 1991), rats (Bonnamy et al., 1990; Sawitzke and Odell, 1991), mice (Ziecik et al., 1992; Mukherjee et al., 1994), heifers (Freidman et al., 1995) and humans (Reshef et al., 1990). Detailed studies in pigs (Ziecik et al., 1986) and women (Reshef et al., 1990) demonstrated the presence of these receptors in both the endometrium and myometrium of the

${ }^{*}$ Correspondence

Revised manuscript received 8 March 1999 uterus. $\mathrm{LH}-\mathrm{hCG}$ receptors have also been detected in the superficial smooth muscle layer of the pig broad ligament and the ligamental blood vessels (Ziecik et al., 1995). After hCG treatment, the majority of vessels supplying and draining blood from the uterus show $\mathrm{LH}-\mathrm{hCG}$ binding sites, as determined by topical autoradiography and increased uterine blood flow in gilts (Ziecik et al., 1996). However, human smooth muscle and the endothelial cells of the umbilical arteries and vein, the umbilical amnion and cells in the Wharton's jelly contain receptor mRNA and receptor proteins that can bind ${ }^{125}$ I-labelled hCG (Rao et al., 1993). The presence of hCG receptors in human umbilical cords indicates that hCG, which is present in cord blood and amniotic fluid, may be directly responsible for the vascular tone and other functions of human umbilical cord. 
The umbilical cord of pigs, like that of humans, contains two thick-walled arteries carrying deoxygenated fetal blood to the placenta and one thin-walled vein carrying oxygenated and nutrient-bearing blood to the fetus. Because there is no evidence of the production of CG by the pig placenta, the present study also investigated whether $\mathrm{LH}-\mathrm{CG}$ receptors are present in the structures of the pig umbilical cord.

\section{Materials and Methods}

\section{Tissues}

Nine Large Polish White pregnant sows (gestation period 113-115 days) were slaughtered and the umbilical cords were taken as soon after death as possible: $8-10$ umbilical cords were taken on days 48,71 and 103 of fetal life. About half of the cords were collected from male and half from female fetuses. The cords were brought to the laboratory in ice cold physiological saline and then washed to remove the blood. Each cord (except those collected on day 48 of fetal life) was cut into three segments. The segment closest to the fetus was considered the fetal portion, the one closest to the placenta, the placental portion, and the remaining portion was considered the middle portion. Cords collected from 48-dayold fetuses were examined in one piece. Ovaries (pig, rat) and pig skeletal muscles were used as positive and negative control tissues, respectively.

All tissues were fixed overnight in $4 \%(\mathrm{w} / \mathrm{v})$ paraformaldehyde in $0.1 \mathrm{~mol}$ phosphate $\mathrm{l}^{-1}$ buffer (PB; $\mathrm{pH} 7.4$ ) at $4^{\circ} \mathrm{C}$ (for autoradiography and immunohistochemistry) and subsequently stored in $18 \%$ sucrose in PB for up to 6 days at $4^{\circ} \mathrm{C}$. The tissues were cut into $12 \mu \mathrm{m}$ thick sections with a cryostat $\left(-25^{\circ} \mathrm{C}\right)$, transferred onto chrome alum-gelatinecoated slides and air-dried for about $20 \mathrm{~min}$. Sections were then frozen at $-30^{\circ} \mathrm{C}$ in air-tight boxes until needed for immunohistochemistry or autoradiography.

\section{Autoradiography}

Highly-purified hCG (CR 127) was labelled with ${ }^{125} \mathrm{I}$ (Amersham, Bucks) according to the chloramine method (Catt and Dufau, 1975; Greenwood et al., 1963). Topical autoradiography was performed as described by Ziecik et al. (1995) with modification.

Before the autoradiographic procedures, the tissues were thawed and rinsed for $20 \mathrm{~min}$ in $50 \mathrm{mmol}$ Tris- $\mathrm{HCl} \mathrm{l}^{-1}, \mathrm{pH}$ 7.4. Each slide was covered with $50-60 \mu \mathrm{l}$ of solution $(50 \mathrm{mmol}$ Tris- $\mathrm{HCl} \mathrm{l} \mathrm{l}^{-1}, 0.1 \mathrm{mmol}$ bacitracin $\mathrm{1}^{-1}, 5 \mathrm{mmol} \mathrm{MgCl}_{2} \mathrm{l}^{-1}$ and $1 \%(\mathrm{w} / \mathrm{v}) \mathrm{BSA} ; \mathrm{pH} 7.4$ ) containing $20-30 \mathrm{pmol}{ }^{125} \mathrm{I}$-labelled $\mathrm{hCG}^{-1}$ and kept in a humid chamber overnight. Nonspecific binding was assessed by incubating adjacent sections with an excess of unlabelled hCG. Preliminary studies revealed that a dose of $1 \mu \mathrm{g} \mathrm{hCG} \mathrm{(CR127)} \mathrm{was} \mathrm{optimal} \mathrm{to} \mathrm{determine}$ the nonspecific binding both in fetal (umbilical cords) and control (ovaries) tissues. After incubation, the sections were washed again in $50 \mathrm{mmol}$ Tris- $\mathrm{HCl} \mathrm{l}^{-1}$, dried at room temperature and exposed in a tight-light cassette at $4^{\circ} \mathrm{C}$ for 20 days to Hyperfilm ${ }^{3} \mathrm{H}$ (Amersham, Uppsala). Films were then developed in Rodinal (Agfa-Gevaert AG, Leverkusen).

\section{Densitometry}

The specific binding ${ }^{125} \mathrm{I}$-labelled hCG in umbilical blood vessels, amnion epithelium and cells of Wharton's jelly was quantified in fetuses using HPScanJet/T scanner (HewlettPackard, Lorvallis, OR) and the Micrograf Picture Publisher LE program.

For each autoradiogram, the mean absorbance of the film was measured over blood vessel walls, amnion epithelium or Wharton's jelly and then diminished for absorbance of autoradiogram exposed to an excess of non-radioactive hCG (nonspecific binding). The mean absorbance for each tissue was determined from the average of at least five measurements made from five autoradiograms containing that region in different fetuses. The values obtained were averaged and expressed as the arbitrary units of grey level. The number of observations $(n)$ was equal to the total number of female or male fetuses from three sows per day of gestation.

After scanning and saving the initial image as a tif file, the file was opened in PhotoStyler Version 2.0 and the scanned image was shown in the greyscale to examine its immunohistological properties (Velleman, 1995). Student's $t$ test for independent samples was used for statistical analysis.

\section{Immunohistochemistry}

Primary antibodies. Polyclonal rabbit antibodies (PR) to synthetic fragments of rat LH receptors [anti-PCR II-(1-11)] were kindly provided by P. C. Roche (Mayo Clinic, Rochester, $\mathrm{MN})$. These antibodies were used at a dilution of $1: 500$.

Polyclonal rabbit antibodies (HR) raised against rat LH receptor (Lakkakorpi et al., 1990) were a gift from I. Huhtaniemi (Turku, Finland). They were used at a dilution of $1: 100$.

Monoclonal antibody (3B5) to rat $\mathrm{LH}$ receptors (Indrapichate et al., 1992) was kindly provided by J. Wimalasena (Knoxville, TN). This antibody was used at a dilution of $1: 50$.

Secondary antibodies. Biotinylated goat anti-rabbit IgG (dilution 1:400 for PR or 1:500 for $\mathrm{HR}$ ) and biotinylated horse anti-mouse IgG (dilution 1:400 for 3B5), used as second antibodies, were from a Vectastain kit (Vector Laboratories Inc., Burlingame, CA).

Immunohistochemistry was performed as follows: slides were taken out of the freezer and air-dried for $10 \mathrm{~min}$. The sections were incubated for $30 \mathrm{~min}$ in $1 \%(\mathrm{v} / \mathrm{v}) \mathrm{H}_{2} \mathrm{O}_{2}$ in methanol to destroy endogenous peroxidases. Sections were then hydrated in PBS ( $\mathrm{pH} 7.4$ ) three times for 10 min each. All incubations were carried out in a humid chamber. Sections were blocked with $2.5 \%$ normal goat serum and $1 \%(\mathrm{w} / \mathrm{v})$ BSA for antibodies PR and HR, or with $2.5 \%$ normal horse serum with $1 \%(\mathrm{w} / \mathrm{v})$ BSA for antibody $3 \mathrm{~B} 5 \mathrm{in}$ PBS, for $60 \mathrm{~min}$ Downloaded from Bioscientifica.com at 04/26/2023 12:47:08PM 
at room temperature to block nonspecific binding of the 'link' antiserum to the tissue. The sections were incubated overnight at room temperature with the primary antibodies at the dilutions listed above. After this incubation, the slides

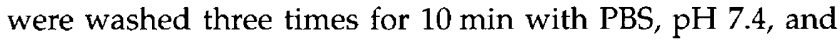
incubated for $60 \mathrm{~min}$ with a biotinylated antibody (the dilution and type of the secondary antibody were matched with the primary antibody). The slides were again washed in PBS and incubated for at least $60 \mathrm{~min}$ with the components, avidin (A) and biotinylated peroxidase (B), of the $A B C$ staining kit (Vectastain). Both components (A and B) were diluted 1:500 and mixed at least $30 \mathrm{~min}$ before application on the sections. The slides were washed again in PBS $(3 \times 10 \mathrm{~min})$ and for $2 \mathrm{~min}$

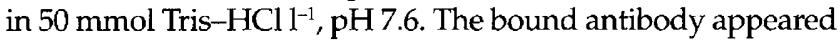

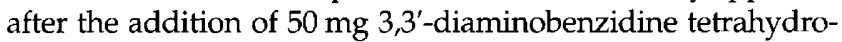
chloride $\mathrm{l}^{-1}$ (Sigma Chemical Co., St Louis, $\mathrm{MO}$ ) in a Tris- $\mathrm{HCl}$ buffer, to which $0.03 \%(\mathrm{v} / \mathrm{v}) \mathrm{H}_{2} \mathrm{O}_{2}$ was added. The sections were then rinsed for $25 \mathrm{~min}$ in running water.

Every fourth section was lightly counterstained (5 min) with Mayer's haematoxylin. Sections were then dehydrated in a series of ethanol solutions, cleared in xylene and mounted with coverslips and DPX.

The following controls were performed: (1) omission of the primary or secondary antibody during the immunostaining procedure; (2) substitution of normal rabbit serum instead of the first polyclonal antibody ( $P R$ and $H R$ ), or normal mouse serum instead of the first monoclonal antibody (3B5); (3) immunostaining of pig ovary (positive control tissue); and (4) immunostaining of pig skeletal muscle (negative control tissue).

Identical conditions were used in the processing of all specimens, including positive and negative control tissues and procedural controls.

\section{Western blotting}

Membrane fractions of umbilical vein, arteries, Wharton's jelly and corpora lutea were prepared as described by Ziecik et al. (1986) with the exception that 0.2 mol Tris- $\mathrm{HCl} \mathrm{l}^{-1}, \mathrm{pH}$ 7.2 buffer, containing $0.1 \mathrm{~mol}$ phenylomethylsulphonyl fluoride $\mathrm{l}^{-1}$ to inhibit the protein activity, was used. Aliquots $(70 \mu \mathrm{g})$ of protein were dissolved in double-strength loading buffer, consisting of $0.5 \mathrm{~mol}$ Tris- $\mathrm{HCl} \mathrm{l}^{-1}(\mathrm{pH} \mathrm{6.8)}, 4 \%(\mathrm{w} / \mathrm{v})$ SDS, $20 \%$ (v/v) glycerol and 2\% (v/v) 2-mercaptoethanol and separated on $10 \%(\mathrm{w} / \mathrm{v})$ SDS-PAGE. The separated proteins were electroblotted onto $0.1 \mu \mathrm{m}$ nitrocellulose membranes for $2 \mathrm{~h}$ at $250 \mathrm{~mA}$ in a $0.025 \mathrm{~mol}$ Tris- $\mathrm{HCl} \mathrm{l}^{-1}$ buffer ( $\mathrm{pH} \mathrm{8.2),}$ $0.192 \mathrm{~mol}$ glycine $\mathrm{l}^{-1}$, containing $0.1 \%(\mathrm{w} / \mathrm{v})$ SDS. The nonspecific binding sites were blocked with $5 \%(\mathrm{w} / \mathrm{v})$ non-fat dry milk in 0.1 mol Tris- $\mathrm{HCl} \mathrm{l}^{-1}$ (pH 7.4), $0.15 \mathrm{~mol} \mathrm{NaCl} \mathrm{l}^{-1}$, $0.1 \%(\mathrm{v} / \mathrm{v})$ Tween-20 (TBST buffer) overnight at $4^{\circ} \mathrm{C}$. The membranes were then incubated with a $1: 1000$ dilution of the $\mathrm{LH}$ receptor antibody (PR) for $1.5 \mathrm{~h}$ at $22^{\circ} \mathrm{C}$ and washed three times for $10 \mathrm{~min}$ each with TBST. The washed blots were reincubated for $1 \mathrm{~h}$ at $22^{\circ} \mathrm{C}$ with a $1: 3000$ dilution of biotinylated antirabbit IgG, washed with TBST and incubated for $1 \mathrm{~h}$ at $22^{\circ} \mathrm{C}$ with a $1: 3000$ dilution of avidinbiotin-horseradish peroxidase (HRPO) complex (Vectastain $\mathrm{ABC}$ kit, Vector Laboratories, Inc, Burlingame, CA). TBS containing $0.01 \%(\mathrm{v} / \mathrm{v}) \quad \mathrm{H}_{2} \mathrm{O}_{2}$ and $0.04 \%(\mathrm{w} / \mathrm{v}) \quad 3,3^{\prime}-$ diaminobenzidine was added to develop the colour.

\section{RNA isolation and reverse transcription-polymerase chain reaction}

Briefly, total RNA was isolated from umbilical cord blood vessels, Wharton's jelly, corpora lutea, intestine and kidney, using the methods of Chomczynski and Sacchi (1987) and Puissant and Houdebine (1990). The purity of RNA was determined by the $A_{260}: A_{280}$ ratio in spectrophotometry and its quality by agarose-formaldehyde gel electrophoresis (Sambrook et al., 1989). The isoforms of the pig LHR cDNA from Gene Bank (pLHRA, pLHRB, pLHRC and pLHRD) were aligned and sequences of splice site junctions in pig LHR cDNA were fitted to this sequence commission.

The oligonucleotides used for RT-PCR were designed using the DNAStar Primer Selection program (DNASTAR Inc. Madison, WI). The specificity of the primers was confirmed by the BLAST Program (Altschul et al., 1990). The sense primer (nucleotides 738-761, exon 9) 5'GACGCTAATTGCCACATCATCCTA was common to all CDNA isoforms, and antisense primer (nucleotides 1456-1475, exon 11) 5'ATTATGCTTGGAGGGTGGCT was related to full length isoform $p L H R A$ and variant $\mathrm{pLHRB}$.

RT-PCR was performed using $2 \mu \mathrm{g}$ total RNA per $100 \mu \mathrm{l}$ reaction mixture. Reverse transcription at $60^{\circ} \mathrm{C}$ for $1 \mathrm{~h}$ and denaturation at $97^{\circ} \mathrm{C}$ for $3 \mathrm{~min}$ were followed by PCR of cDNA at 40 cycles, including denaturation at $96^{\circ} \mathrm{C}$ for $30 \mathrm{~s}$, primer annealing at $55^{\circ} \mathrm{C}$ for $30 \mathrm{~s}$ and extension at $74^{\circ} \mathrm{C}$. Tth DNA polymerase, having both reverse transcriptase and DNA polymerase activities (Epicentre Technologies, Madison, WI), was used. The PCR products $(20 \mu \mathrm{l})$ were subjected to electrophoresis on $1 \%(\mathrm{w} / \mathrm{v})$ agarose gel and photographed under UV light.

The primers selection program (DNAStar) was used to predict the annealing temperature, and the alignment of the pig LHR sequence predicted two RT-PCR products of 740 and $470 \mathrm{bp}$, respectively.

\section{Southern hybridization}

The RT-PCR products $(10 \mu 1)$ were subjected to electrophoresis on $1.5 \%(\mathrm{w} / \mathrm{v})$ agarose gels and transferred on nylon filter (Hybond $\mathrm{N}$, Amersham) using the standard procedure. The hybridization was performed according to hybridization protocols for nylon membranes (Hybond $\mathrm{N}$, Amersham) with a pig cDNA probe (fragment 900-2081 of pig LHR cDNA) labelled with $\left[\alpha-{ }^{32} \mathrm{P}\right] \mathrm{dCTP}$, using the random prime method (Multiprimer ${ }^{\mathrm{TM}}$ DNA Labelling System, GIBCO $\mathrm{BRL}$, Gaithersburg, MD), at $65^{\circ} \mathrm{C}$ for $12 \mathrm{~h}$. The pig $\mathrm{LH}$ receptor cDNA was obtained from $\mathrm{Dr} \mathrm{H}$. Loosfelt (Hormones at Reproduction, Hospital de Biocentre, Kremlin Biocentre, Paris). After hybridization, the blots were washed twice with $1 \times \operatorname{SSC}\left(0.15 \mathrm{~mol} \mathrm{NaCl}^{-1}, 15 \mathrm{mmol}\right.$ sodium citrate $\left.\mathrm{l}^{-1}, \mathrm{pH} 7.0\right)$ containing $0.1 \%$ SDS for $15 \mathrm{~min}$ at room temperature, and twice with $0.2 \times \mathrm{SSC}-0.1 \% \mathrm{SDS}$ at $65^{\circ} \mathrm{C}$ for $15 \mathrm{~min}$. The washed sheets were exposed to Amersham X-ray film at $-80^{\circ} \mathrm{C}$. 

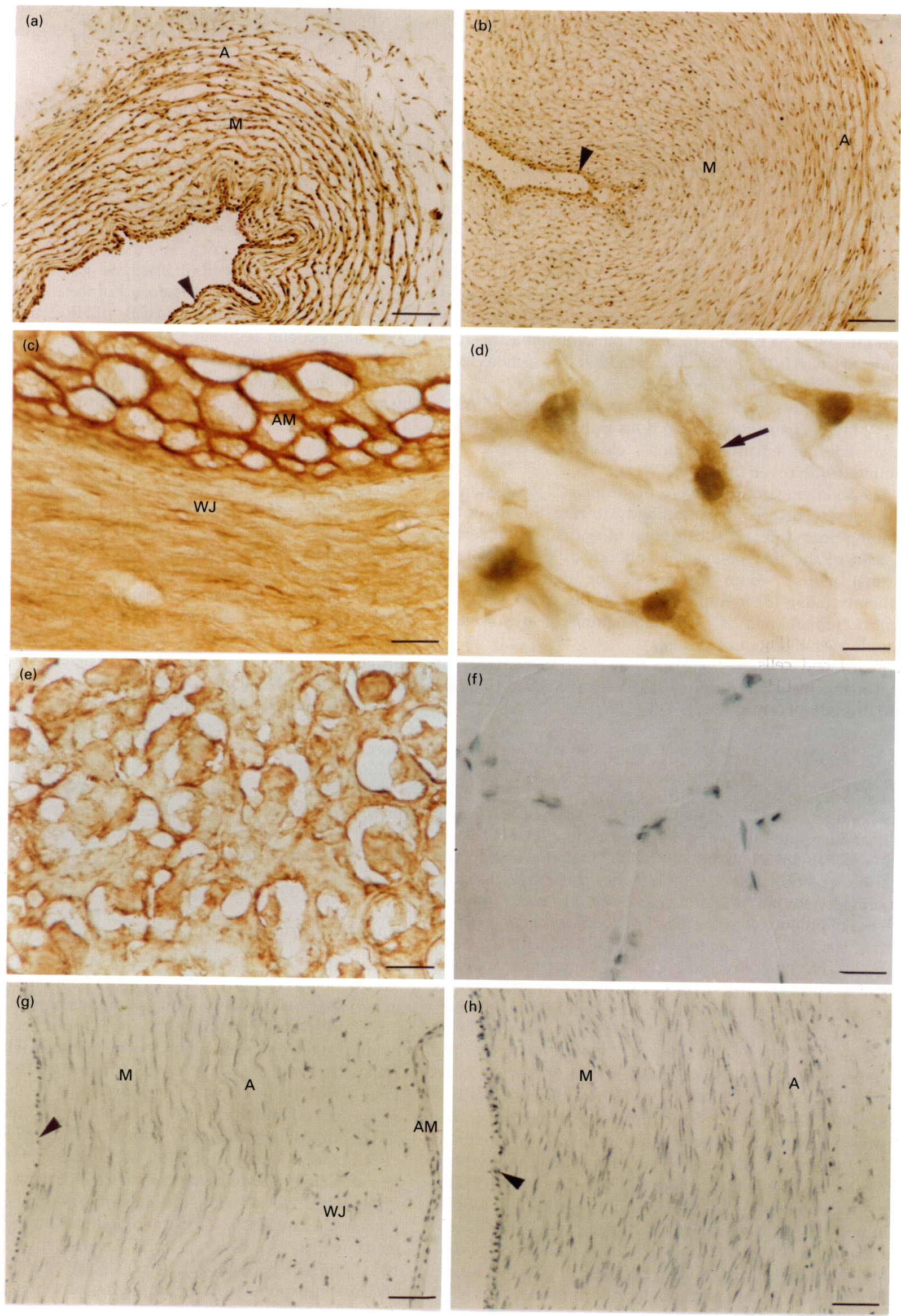
Table 1. Summary of staining of umbilical cord and control tissues

\begin{tabular}{lccc}
\hline & & Day of fetal life & \\
\cline { 2 - 4 } Tissue & 48 & 71 & 103 \\
\hline Arteries & & & ++ \\
$\quad$ Tunica intima & ++ & ++ & + \\
$\quad$ Tunica media & + & + & ++ \\
$\quad$ Tunica adventitia & ++ & ++ & ++ \\
Vein & & ++ & ++ \\
Tunica intima & ++ & ++ & ++ \\
Tunica media & ++ & ++ & + \\
$\quad$ Tunica adventitia & ++ & ++ & 0 \\
Amnion epithelium & ++ & + & ++ \\
Cells of Wharton's jelly & + & ND & \\
Vein incubated with NRS & ND & +++ & \\
Corpus luteum (positive control) & & 0 & \\
Skeletal muscle (negative control) & & & + \\
\hline
\end{tabular}

Scoring of intensity of staining from 0 to +++ (expressed as arbitrary units of grey level; $0: 0-18 ;+: 19-43 ;++44-101 ;+++>101$; ND: not determined).

\section{Results}

\section{Immunolocalization of the $L H-h C G$ receptors in pig umbilical cord}

Immunohistochemistry showed receptors in the umbilical blood vessels (Fig. 1a,b), epithelium of umbilical amnion (Fig. 1c) and cells in the Wharton's jelly (Fig. 1c,d). No differences in LH-hCG receptor distribution related to the sex of fetus, period of the fetal life or part of the umbilical cord were observed.

There was strong immunostaining in the umbilical vein (Fig. 1a) and in the umbilical arteries (Fig. 1b; Table 1). The LH-hCG receptor was detected in the tunica intima, media and adventitia of the umbilical vein (Fig. 1a). However, in the arteries, the tunica media showed weaker receptor immunostaining than did the tunica intima and adventitia (Fig. 1b; Table 1).

Receptor immunostaining was stronger in the umbilical amniotic epithelium (Fig. 1c) than it was in the Wharton's jelly (Fig. 1c,d; Table 1).

The pig corpora lutea (Fig. 1e) were immunostained with specific receptor antibodies to confirm this specific immunostaining technique. LH-hCG receptors were not detectable in pig skeletal muscles (Fig. 1f). Umbilical vein with Wharton's jelly plus amnion epithelium (103-day-old fetus) was incubated with normal rabbit serum (Fig. 1g). There was no binding of nonspecific IgG. Identical immunostaining results were obtained with both $\mathrm{HR}$ and $\mathrm{PR}$ antibodies. However, significantly weaker staining was seen after application of 3B5 antibody and, for this reason, HR and PR antibodies were used to localize $\mathrm{LH}-\mathrm{hCG}$ receptors in pig umbilical cord.

\section{Localization of hCG-binding sites with autoradiography}

The tissue localization of LH-hCG receptors was assessed on the sections that had been used to produce the autoradiograms (Fig. 2). Analysis of autoradiograms revealed that $\mathrm{LH}-\mathrm{hCG}$ receptors are situated in both arteries and vein as well as in the Wharton's jelly of umbilical cord and the epithelial cells of umbilical amnion (Fig. 2b). Incubation of sections with non-radioactive hormone significantly displaced ${ }^{125}$-labelled hCG binding (Fig. 2d). In addition to the above control for umbilical cord, other negative and positive tissues were also tested: pig skeletal muscle (negative control) did not show the presence of gonadotrophin binding sites (Fig. 2c); and pig ovary from the luteal phase (positive control) showed strong binding of 125I-labelled hCG in follicles and corpora lutea (Fig. 2a). A computer-generated image of autoradiograms of umbilical

Fig. 1. Immunohistochemistry of LH-hCG receptors in pig umbilical cords. (a) Umbilical vein of 71-day-old male fetus (middle part of the umbilical cord); (b) umbilical artery of 71-day-old female fetus (periplacental part of the umbilical cord); (c) epithelium of umbilical amnion and Wharton's jelly of 103-day-old male fetus (perifetal part of the umbilical cord); (d) cells of Wharton's jelly of 103-day-old female fetus (middle part of the umbilical cord); (e) pig corpus luteum; (f) pig skeletal muscle (negative control tissue); (g) umbilical amnion, Wharton's jelly and umbilical vein of 103-day-old female fetus (periplacental part of umbilical cord); (h) umbilical artery of 103-day-old female fetus (middle part of the umbilical cord). Plates show sections stained with polyclonal rabbit antibodies, except (g) and (h), in which normal rabbit serum was substituted for primary antibody. $(a, b, d, f, g, h)$ Nuclei counterstained with Mayer's haematoxylin. Photographs were made using a light microscope (Axioskop, Zeiss). Photographs (c,d,e,f) were made using Nomarsky optics. Arrow: cell of Wharton's jelly; arrowhead: tunica intima; A: tunica adventitia; AM: amniotic epithelium; M: tunica media; WJ: Wharton's jelly. Scale bars represent (a) $200 \mu \mathrm{m},(\mathrm{b}, \mathrm{g}, \mathrm{h}) 100 \mu \mathrm{m}$, (c,e,f) $25 \mu \mathrm{m}$ and (d) $10 \mu \mathrm{m}$. 


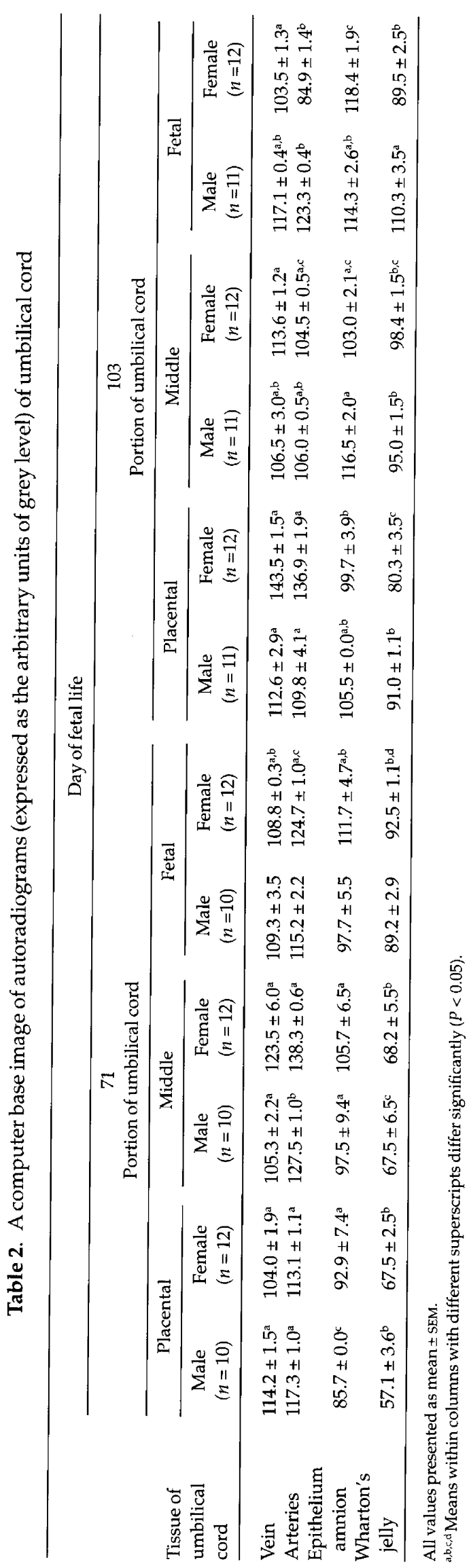




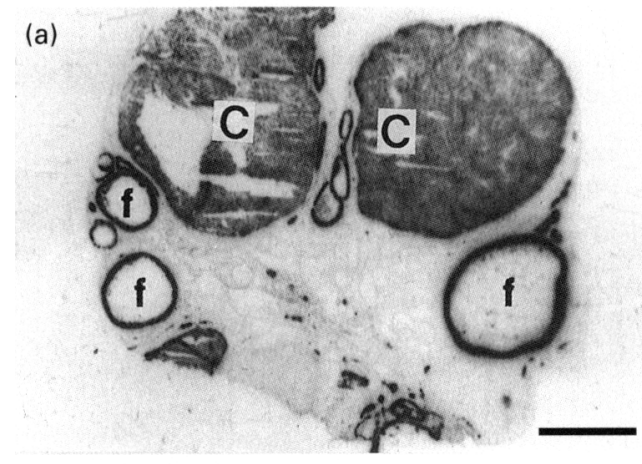

(c)

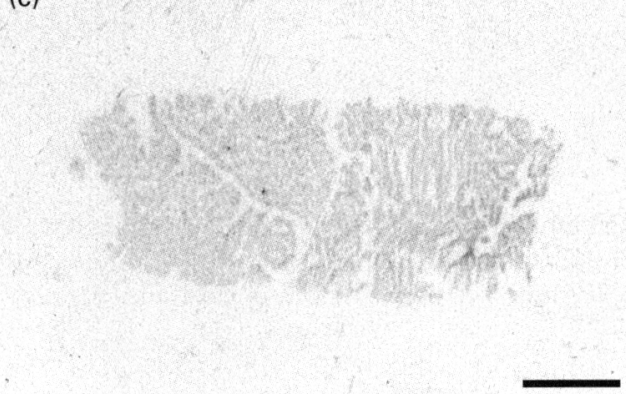

(b)

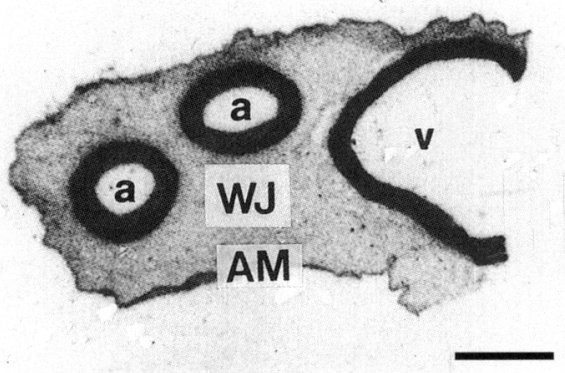

(d)

\footnotetext{
Fig. 2. Autoradiography of LH-hCG receptors in pig umbilical cords, positive and negative controls. ${ }^{125}$ I-labelled hCG was present in $(a-c)$ and unlabelled hCG was present in (d). (a) Pig ovary from luteal phase; (b,d) umbilical vein and umbilical arteries (103-day-old fetus); (c) pig skeletal muscle. a: artery; AM: amniotic epithelium; c: corpora lutea; f: follicle; v: vein; WJ: Wharton's jelly. Scale bars represent (a) $5 \mathrm{~mm}$ and (b-d) $2 \mathrm{~mm}$.
}

cord in 48-day-old fetuses showed that the umbilical arteries and vein contained relatively large amounts of grey (arbitrary units: mean \pm SEM) both in males $(130.5 \pm 0.5$ and $134.4 \pm 0.5 ; n=13)$ and females (142.3 \pm 0.5 and $149.2 \pm 0.7$; $n=14$, respectively) when compared with male $(60.4 \pm 8.9$; $P<0.05)$ and female $(118.6 \pm 2.0)$ amniotic epithelium or male and female Wharton's jelly ( $56.3 \pm 3.5$ and $68.5 \pm 0.5$, $P<0.05$, respectively).

The results of densitometry of autoradiograms for different portions of umbilical cords collected from fetuses on days 71 and 103 of gestation are shown (Table 2). As was the case in 48-day-old fetuses, the umbilical cord arteries and vein of 71- and 103-day-old fetuses showed greater increases in the concentrations of LH-hCG receptors than did the Wharton's jelly in the placental and middle portion of umbilical cord $(P>0.05)$ in both sexes. However, there was little difference in the fetal portion of umbilical cord (Table 2). In general, the epithelial amnion showed a concentration of binding sites that was a little lower than that of blood vessels and a little higher than that of the Wharton's jelly of the umbilical cord.

\section{$L H-h C G$ receptor protein}

Western immunoblotting with a polyclonal LH-hCG receptor antibody showed that umbilical arteries and vein contained a $75 \mathrm{kDa}$ protein (Fig. 3; lines 3-5). There was also

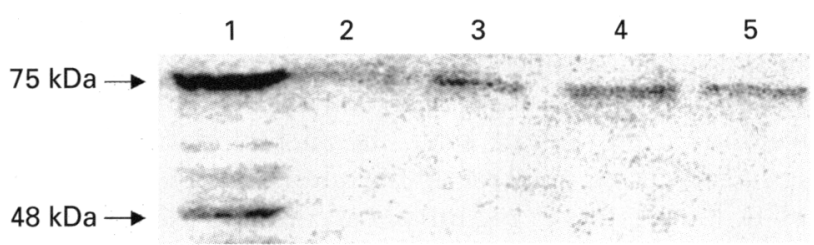

Fig. 3. Western immunoblotting for pig LH-hCG receptors. Line 1: pig corpora lutea; line 2: Wharton's jelly; line 3: umbilical vein; lines 4 and 5: umbilical arteries of 103-day-old fetus. Forty milligrams of protein of each tissue was used.

a weak receptor protein band in Wharton's jelly (line 2). Corpora lutea contained two receptor proteins of 75 and $48 \mathrm{kDa}$ (line 1). The skeletal muscle did not show receptor protein (data not shown).

\section{LH-hCG receptor $m R N A$}

A Southern blot of RT-PCR products was performed to enhance the specificity of determinations of LH receptor transcripts in umbilical cord tissues (Fig. 4) and revealed that the expected fragments of 740 and 470 bp were present in the vein and arteries and Wharton's jelly of the umbilical cord as well as in corpora lutea (positive control). However, the signals for Wharton's jelly were very weak. An additional product of $670 \mathrm{bp}$ was found in the corpora lutea and arteries 

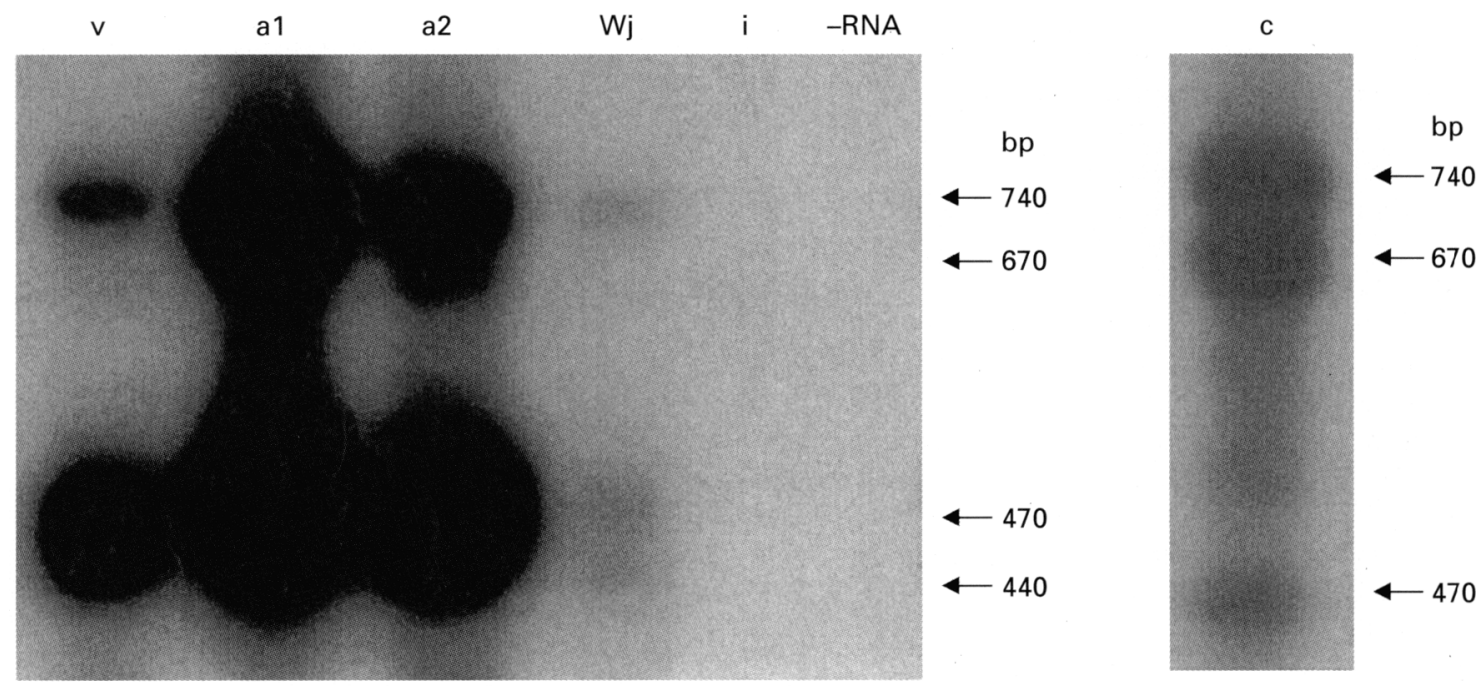

Fig. 4. Southern blot of RT-PCR products of pig LH receptor in umbilical cord tissues. a: artery; c: corpora lutea (positive control); i: intestine (negative control); -RNA: reaction control without RNA; v: vein; Wj: Wharton's jelly. After hybridization, the membrane was exposed to Amersham X-ray film 3 days for umbilical cord and negative control tissues, respectively, and for $2 \mathrm{~h}$ for corpora lutea.

of the umbilical cord, but not in the vein and Wharton's jelly. The negative control tissue (for example, intestine and kidney tissue; data not shown) and the control of RT-PCR reaction (tube without RNA) did not show the presence of any RT-PCR products.

\section{Discussion}

The presence of functional LH-hCG receptors in human umbilical cords (Rao et al., 1993) and the discovery of similar receptors in the uterine broad ligamental blood vessels in pigs (Ziecik et al., 1995) raised the question of the presence of LH-hCG receptors in pig umbilical cord and their biological significance.

The results of the present study showed the presence of LH-hCG receptors in pig umbilical cord. Two methods were used to visualize $\mathrm{LH}$ receptors in the umbilical cord: immunostaining and autoradiography. Both methods gave consistent results and showed the highest intensity of LH receptor immunostaining or ${ }^{125} \mathrm{I}$-labelled $\mathrm{hCG}$ binding in umbilical cord vessels and the lowest in cells of the Wharton's jelly. A small divergence of results between both methods was found only in umbilical veins and arteries, since immunostaining was usually stronger in veins than in arteries. However, autoradiograms in most cases did not show significant differences. A relatively high concentration of $\mathrm{LH}$ receptors was found in the amniotic epithelium using both immunostaining and autoradiography. The distribution of gonadotrophin receptors in pig cords was similar to that in humans and there were no consistent differences in receptor expression between cords from male and female pig fetuses. In the present study, in pigs, the higher receptor expression in the blood vessels of the fetal portion of the cord than in the placental portion as reported in humans (Rao et al., 1993) was not observed. The various portions (fetal, middle and placental) of the pig umbilical cord and cells in Wharton's jelly with the amniotic epithelium showed a similar distribution of LH-hCG receptor immunostaining. The autoradiographical method of receptor identification did not have as strong a reaction as did the immunohistochemical reaction in epithelial cells of umbilical amnion, particularly on day 103 of fetal life.

The cloning and sequencing of pig LH-hCG receptor messenger RNAs revealed the presence of a full-length receptor and shorter variants, lacking either the transmembrane and the intracellular domains or only the transmembrane domain. Immunoblotting of testicular membrane extracts detected 85,68 and $45-48 \mathrm{kDa}$ proteins reacting with anti-receptor antibodies (Vu Hai-Luu Thi et al., 1992). The main full-length receptor species $(85 \mathrm{kDa})$ present in the pig testis contains complex oligosaccharides. The present study showed that pig corpora lutea and umbilical cord vessels contain mainly the $75 \mathrm{kDa}$ receptor species, which is in agreement with the molecular mass for LH receptor in pigs calculated by Loosfelt et al. (1989). This protein contains an extracellular domain of 333 amino acids proceeding a 266 amino acid transmembrane region (with seven transmembrane spans) and a 70 amino acid intracellular domain. However, it is hypothesized that the $75 \mathrm{kDa}$ protein found in the present study is the glycosated $68 \mathrm{kDa}$ form described by Vu Hai-Luu Thi et al. (1992) in pig testis. The $48 \mathrm{kDa}$ receptor variant detected in pig corpora lutea is apparently a form lacking transmembrane or intracellular domains. Western immunoblotting showed receptor protein in Wharton's jelly and Southern blot analysis revealed the presence of mRNA transcripts. The low LH immunostaining and the relatively low binding of ${ }^{125}$ I-labelled $\mathrm{hCG}$ indicated that LH receptors in Wharton's jelly are very dispersed. The pig luteotrophin receptor has four splice variants (Loosfelt $e t$ al., 1989), and the three shorter variants are caused by alternative splicing of exon 10 with exon 11 . These shorter isoforms were observed in the testes and two variants 
encoded proteins lacking both transmembrane and intracellular domains and the third encoded only the transmembrane domain. Although there are no data to confirm that some isoforms of $\mathrm{LH}$ receptors differ in their binding affinity, the presence of $\mathrm{LH}$ receptor variants in nongonadal reproductive tissues may explain, in part, the variance in the results from the immunocytochemical and autoradiographical analyses in the present study.

The umbilical cord provides a vascular connection between fetus and mother via the placenta. The umbilical vessels are surrounded and protected by the Wharton's jelly, which contains modified fibroblasts known as myofibroblasts (Takechi et al., 1993). These cells contribute to the elasticity of the Wharton's jelly by synthesizing collagen fibres and may play a role in the regulation of umbilical blood flow. LH-hCG umbilical cord receptors in humans are functionally coupled to the regulation of the eicosanoid biosynthetic pathway (Rao et al., 1993) and may mediate hCG action on the relaxation of umbilical blood vessels. Such an action would increase the blood flow between fetus and placenta and play an important role in fetal growth and development. Since it has been established that human cord blood (Crosignani et al., 1972) and amniotic fluid contain hCG (Clements et al., 1976; Ozturk et al., 1988), the physiological importance of $\mathrm{LH}-\mathrm{hCG}$ receptors is clear. The biological significance discovered in the present study on $\mathrm{LH}-\mathrm{hCG}$ receptors in pig umbilical cord is more difficult to explain because the presence of chorionic gonadotrophin in pig placenta has yet to be proved. However, Saunders et al. (1980) reported the presence of a gonadotrophin-like substance in fetal membranes and allantoic fluid on days 52 and 66 of gestation and in placenta at term. The gonadotrophin-like material in the trophoblast was shown to be distinct from pig LH by subjecting the same extracts to specific radioimmunoassay for $\mathrm{LH} ;<8 \%$ of the material that crossreacted in radioreceptor assays could be accounted for by pLH. Whether LH-hCG receptors in the pig umbilical cord are functional and able to bind unknown gonadotrophin-like hormones, or are merely a philogenetical dead end, remains to be elucidated.

The authors are indebted to K. Wasowicz for his help with the immunohistochemical experiments and to $M$. Jensen for editing the manuscript. They would like to express gratitude to J. MurawskaKempa for typing this manuscript. Some of the results were communicated in a preliminary form at the 13th International Congress on Animal Reproduction in Sydney, Australia, June 30-July 4, 1996. The studies were supported by the State Committee for Scientific Research in Poland (Grant 5 P06K 039 09).

\section{References}

Altschul S, Gish W, Miller W, Myers E and Lipman D (1990) Basic local alignment search tool Journal of Molecular Biology 215 403-410

Bonnamy PJ, Benhaim A and Leymarie P (1990) Estrous cycle-related changes of high affinity luteinizing hormone/human chorionic gonadotropin binding site in the rat uterus Endocrinology 126 1264-1269

Catt KJ and Dufau ML (1975) Gonadal receptors for luteinizing hormone and chorionic gonadotrophin Methods in Enzymology 37 167-193

Chomczynski P and Sacchi N (1987) Single-step method RNA isolation by acid guanidinum thiocinate-phenol-chloroform extraction Analytical Biochemistry 162 156-159

Clements JA, Reyes FI, Winter JSD and Faiman C (1976) Studies of human sexual development III. Fetal pituitary and serum, and amniotic fluid concentrations of L.H, CG, and FSH Journal of Clinical Endocrinology and Metabolism 429-19

Crosignani PG, Nencioni T and Brambati B (1972) Concentration of chorionic gonadotrophin and chorionic somatomammotrophin in maternal serum, amniotic fluid and cord blood serum at term Journal of Obstetrics and Gynaecology 79 122-126

Freidman S, Gurevich M and Shemesh M (1995) Bovine cyclic endometrium contains high-affinity luteinizing hormone/human chorionic gonadotropin binding sites Biology of Reproduction 52 1020-1026

Greenwood FC, Hunter WH and Glover JS (1963) The preparation of ${ }^{131} \mathrm{I}$ labelled human growth hormone of high specific radioactivity Biochemical Journal 89 114-123

Indrapichate K, Meehan D, Lane TA, Chu SY, Rao ChV, Johnson D, Chen TT and Wimalasena J (1992) Biological actions of monoclonal luteinizing hormone/human chorionic gonadotropin receptor antibodies Biology of Reproduction 46 265-278

Jensen JD and Odell WD (1988) Identification of LH/hCG receptors in rabbit uterus Proceedings of Society of Experimental Biology and Medicine 189 28-30

Lakkakorpi J, Keinänen KP and Rajaniemi H (1990) Production and characterization of polyclonal antiserum to rat luteinizing hormone/chorionic gonadotropin receptor and its immunohistochemical application for studying receptor location and downregulation Endocrinology 127 513-522

Loosfelt H, Misrahi M, Atger M, Salesse R, Vu Hai-Luu Thi MT, Jolivet A, Guiochon-Mantel A, Sar S, Jallal B, Garnier J and Milgrom E (1989) Cloning and sequencing of porcine $\mathrm{LH}-\mathrm{hCG}$ receptor cDNA: variants lacking transmembrane domain Science 245 525-528

Mukherjee D, Manna PR and Bhattacharya S (1994) Functional relevance of luteinizing hormone receptor in mouse uterus Europenn Journal of Endocrinology 131 103-108

Ozturk M, Brown N, Milunsky A and Wands J (1988) Physiological studies of human chorionic gonadotropin and free subunits in the amniotic fluid compartment compared to those in maternal serum Journal of Clinical Endocrinology and Metabolism $671117-1121$

Puissant C and Houdebin LM (1990) An improvement of the single-step method of RNA isolation by acid guanidinium thiocyanate-phenolchloroform extraction BioTechniques 8 148-149

Rao ChV, Li X, Toth P, Lei ZM and Cook VD (1993) Novel expression of functional human chorionic gonadotropin/luteinizing hormone receptor gene in human umbilical cords Journal of Clinical Endocrinology and Metabolism 77 1706-1714

Reshef E, Lei ZM, Rao ChV, Pridham DD, Chegini N and Luborsky JL (1990) The presence of gonadotropin receptors in nonpregnant human uterus, human placenta, fetal membranes, and decidua Journal of Clinical Endocrinology and Metabolism 70 421-430

Sambrook J, Fritsch EF and Maniatis T (1989) Molecular cloning: a laboratory manual Cold Spring Harbor Laboratory Press, Cold Spring Harbor, NY

Saunders PTK, Ziecik AJ and Flint APF (1980) Gonadotrophin-like substance in pig placenta and embryonic membranes Journal of Endocrinology $8525 \mathrm{P}$

Sawitzke AL and Odell WD (1991) Uterine binding sites for LH/hCG can be modulated by hormonal status in rabbits and rats Acta Endocrinologica (Copenhagen) 124 322-330

Takechi K, Kuwabara $\mathbf{Y}$ and Mizuno $\mathbf{M}$ (1993) Ultrastructural and immunocytochemical studies of Wharton's jelly umbilical cord cells Placenta $14235-245$

Velleman SG (1995) Quantifying immunoblots with a digital scanner BioTechniques 18 1056-1058

Vu Hai-Luu Thi MT, Misrahi M, Houllier A, Jolivet A and Milgrom E (1992) Variant forms of the pig lutropin/choriogonadotropin receptor Biochemistry $318377-8383$

Ziecik AJ, Stanchev PD and Tilton JE (1986) Evidence for the presence of luteinizing hormone/human chorionic gonadotropin-binding sites in the porcine uterus Endocrinology 119 1159-1163

Ziecik AJ, Derecka-Reszka K and Rzucidlo JS (1992) Extragonadal gonadotropin receptors, their distribution and function Journal of Physiology and Pharmacology $4333-49$

Ziecik AJ, Ostrowska G, Kisielewska J and Zezula-Szpyra A (1995) Distribution and cycle phase dependency of gonadotropin receptors in musculature and blood vessels of the porcine broad ligament Experimental and Clinical Endocrinology and Diabetes 103 44-51

Ziecik AJ, Golba G and Kisielewska J (1996) Effect of human chorionic gonadotropin on uterine blood flow in intact and ovariectomized gilts Experimental and Clinical Endocrinology and Diabetes 104 158-163 